\title{
ANALISIS PENGARUH KEMAMPUAN, USAHA DAN DUKUNGAN PERUSAHAAN TERHADAP KINERJA KARYAWAN PADA CV SANDANG GLORIA KONVEKSINDO
}

\author{
Jerry Logahan; Synthia Atas Sari; Dian Marisa
}

Jurusan Manajemen, Fakultas Ekonomi dan Komunikasi, BINUS University

Jln. K.H. Syahdan No. 9, Palmerah, Jakarta Barat 11480

\begin{abstract}
Clothing Konveksindo CV Gloria is a trading company engaged in the sale of products and clothing items. Therefore, the performance of employees is very important in achieving that goal. The purpose of this study was to analyze the influence of ability, effort, and support the company towards the employee's performance CV Gloria Konveksindo Clothing. The method of analysis used in this study is descriptive, Pearson Regression, and Multiple Regression. Data obtained from the appraisal of employee performance by filling in the questionnaire that has been provided by using a Likert scale that is useful to know the degree of disagreement and agreement existing employees to the question on the questionnaire. The results achieved in this study were the ability of employees to work have an influence for $28.8 \%$ of employee performance, employee efforts in working to have the effect of $50.6 \%$ on employee performance, corporate support for work processes have the effect of $47.7 \%$ the performance of employees, while the ability of employees, employee efforts, and support the company has influence for $66.3 \%$ of the employee's performance CV Gloria Konveksindo Clothing. With this capability expected of employees, employee efforts, and support the company serve as the main factor to improve employee performance.
\end{abstract}

Keywords: the ability of employees, employee efforts, the company's support, employee performance

\begin{abstract}
ABSTRAK
CV Gloria Clothing Konveksindo adalah perusahaan perdagangan yang bergerak di bidang penjualan produk dan pakaian. Oleh karena itu, kinerja pekerja sangat penting dalam mencapai tujuan tersebut. Tujuan penelitian ini adalah untuk menganalisis pengaruh kemampuan, daya, dan dukungan perusahaan terhadap kinerja karyawan di CV Gloria Clothing Konveksindo. Metode analisis yang digunakan dalam penelitian ini adalah metode deskriptif dengan menggunakan Pearson Regression tunggal dan berganda. Data yang diperoleh berasal dari penilaian kinerja karyawan dengan mengisi kuesioner yang telah disediakan dengan menggunakan skala Likert yang berfungsi untuk mengetahui tingkat setuju dan tidak setuju karyawan terhadap pertanyaan kuesioner. Hasil yang didapatkan dari penelitian ini adalah kemampuan karyawan untuk bekerja memengaruhi $28.8 \%$ dari kinerja karyawan, usaha karyawan dalam bekerja berdampak $50.6 \%$ pada kinerja karyawan, dukungan perusahaan terhadap proses kerja memiliki efek $47.7 \%$ pada kinerja karyawan, sementara kemampuan karyawan, usaha karyawan, dan dukungan perusahaan berpengaruh $66.3 \%$ terhadap kinerja karyawan CV Gloria Konveksindo Clothing. Dengan kemampuan yang diharapkan dari karyawan, usaha karyawan, dan dukungan perusahaan bisa berfungsi sebagai faktor utama untuk meningkatkan kinerja karyawan.
\end{abstract}

Kata kunci: kemampuan karyawan, usaha karyawan, dukungan perusahaan, kinerja karyawan 


\section{PENDAHULUAN}

Sumber daya manusia merupakan aset besar untuk kelangsungan perusahaan pada masa yang akan datang. Berjalan dengan itu, makan akan muncul pula permasalahan baru berkaitan dengan penyediaan sumber daya manusia yang bermutu. Permasalahan tersebut juga dirasakan oleh perusahaan-perusahaan saat ini, termasuk CV Sandang Gloria Konveksindo Karena bagaimanapun majunya perusahaan tanpa adanya sumber daya manusia tidak mungkin berjalan dengan sendirinya. CV Sandang Gloria Konveksindo merupakan perusahaan yang bergerak di bidang konveksi, yakni dari proses merajut benang sampai akhir proses pembuatan pakaian. Perusahaan ini memiliki misi yaitu: Mengembangkan kemampuan teknologi yang modern, menjaga kualitas hasil produksi dan menerapkan prinsip karyawan adalah partner kerja bukan merupakan aset perusahaan. Tenaga kerja pada dasarnya harus dianggap teman kerja, karena sebenarnya antara perusahaan dan tenaga kerja adalah saling membutuhkan. Setiap karyawan yang bekerja disuatu perusahaan pasti memiliki masalah terhadap pekerjaannya misalnya seperti konflik kerja, beban kerja, waktu kerja, tugas kerja dan pengaruh dari lingkungan kerjanya. Kesulitan tersebut dapat berupa kemampuan seorang karyawan dalam melakukan pekerjaannya dan usaha karyawan tersebut mengerjakan tugas dari atasannya. Proses komunikasi antara manajer dan karyawan dapat mengidentifikasi penyebab dari kesulitan dan masalah yang dialami oleh karyawan tersebut, karena masalah akan selalu menimpa karyawan maupun perusahaan dan menghambat perusahaan untuk berkembang.

Setiap perusahaan harus memiliki rencana dimana pimpinan dan karyawan dapat bekerja dengan baik. Kinerja seorang karyawan akan lebih baik jika karyawan tersebut memiliki kemampuan yang tinggi, usaha yang besar dan dukungan dari perusahaan tersebut. Rajin dalam mengerjakan pekerjaan dan bersedia bekerja karena digaji sesuai dengan tingkat pekerjaannya. Gaji merupakan suatu hal yang mendorong karyawan untuk menyelesaikan tugasnya dengan baik. CV Sandang Gloria Konveksindo pasti memiliki beberapa masalah seperti apakah kinerja karyawan sudah berjalan dengan baik, bagaimana kemampuan karyawan, usaha karyawan, serta dukungan perusahaan agar perusahaan dapat berjalan dengan baik. Dari latar belakang tersebut, maka identifikasi masalah yang akan muncul adalah: (1) apa pengaruh kemampuan karyawan terhadap kinerja karyawan; (2) apa pengaruh usaha karyawan terhadap kinerja karyawan; (3) apa pengaruh dukungan dari perusahaan terhadap kinerja karyawan; dan (4) apa pengaruh antara kemampuan karyawan, usaha karyawan dan dukungan perusahaan terhadap kinerja karyawan.

\section{Kerangka Teori}

Dalam mengembangkan kemampuan, kecekatan dan keahlian para pegawai, pekerja atau karyawan baru diperlukan pemberian pendidikan dan pelatihan/diklat yang disuaikan dengan bidang kerjanya. Beberapa cara atau metode yang dapat digunakan untuk mengembangkan keterampilan pegawai baru, yaitu: (1) magang/apprenticeship training, adalah suatu pembekalan pegawa baru dengan cara belajar langsung dengan senior dan diawasi oleh para pakar atau ahlinya. Untuk mendapatkan kemampuan yang sama dengan masternya dibutuhkan waktu yang relatif cukup lama; (2) learning by doing/on the job training/bekerja sambil belajar, adalah suatu bentuk pembekalan yang dapat mempercepat proses pemindahan pengetahuan dan pengalaman kerja/transfer knowledge dan para karyawan senior ke junior. Pelatihan ini langsung menerjunkan pegawai baru bekerja sesuai dengan job description masing-masing di bawah supervisi/pengawasan penyelia atau karyawan senior; (3) vestibule training, adalah memberikan pelatihan semacam kursus yang dijalankan di luar lingkungan kerja. Pendidikan dan pelatihan yang diberikan pada kursus tersebut tidak jauh berbeda dengan pekerjaan yang nantinya akan digeluti oleh para peserta.

Macam- macam tenaga kerja berdasarkan keahlian/kemampuan, baik yang terdidik, terlatih \& tidak terdidik dan tidak terlatih. Tenaga kerja terdidik adalah tenaga kerja yang mendapatkan suatu 
keahlian atau kemahiran pada suatu bidang karena sekolah atau pendidikan formal dan non formal. Contohnya seperti sarjana ekonomi, insinyur, sarjana muda, doktor, master, dan lain sebagainya.

Tenaga kerja terlatih adalah tenaga kerja yang memiliki keahlian dalam bidang tertentu yang didapat melalui pengalaman kerja. Keahlian terlatih ini tidak memerlukan pendidikan karena yang dibutuhkan adalah latihan dan melakukannya berulang-ulang sampai bisa dan menguasai pekerjaan tersebut. Contohnya adalah supir, pelayan toko, tukang masak, montir, pelukis, dan lain-lain. Tenaga kerja tidak terdidik dan tidak terlatih adalah tenaga kerja kasar yang hanya mengandalkan tenaga saja. Contoh tenaga kerja model ini seperti kuli, buruh angkut, buruh pabrik, pembantu, tukang becak, dan masih banyak lagi contoh lainnya.

\section{Analisis Pekerjaan (Job Analysis)}

Job Analysis merupakan Proses yang sistematis dari menghimpun informasi dari tugas, kewajiban dan tanggung jawab dari pekerjaan tertentu.

Hubungan analisa pekerjaan dengan kemampuan karyawan, yaitu: (1) untuk mengukur prestasi kerja, yaitu sejauh mana karyawan dapat sukses dalam pekerjaannya; (2) sebagai alat untuk meningkatkan motivasi karyawan; (3) sebagai alat untuk mendorong para atasan untuk mengobservasi perilaku bawahan; (4) sebagai alat untuk melihat kelemahan karyawan dimasa lalu dan akan meningkatkan kemampuan karyawan selanjutnya; (5) sebagai kriteria dalam menentukan seleksi dan penempatan karyawan.

\section{Kemampuan Individu}

Menurut Malthies (2006) instrumen yang mempengaruhsi kemampuan ada tiga, yaitu bakat, minat dan faktor kepribadian. Bakat adalah kemampuan yang ada pada seseorang yang dibawanya sejak lahir, yang diterima sebagai warisan dari orang tua. Bakat-bakat yang dimiliki karyawan tersebut, apabila diberi kesempatan untuk dikembangkan, maka akan mencapai kinerja yang lebih tinggi. Oleh karena itu, dalam memilih sebuah bidang pekerjaan sebaiknya karyawan melihat aspek bakat yang ada pada dirinya.

Minat adala suatu posisi yang terorganisir melalui pengalaman yang mendorong seseorang untuk memperoleh objek khusus, aktivitas, pemahaman, dan keterampilan untuk tujuan perhatian atau pencapaian. Minat yang tinggi pada suatu pekerjaan akan memberi dampak yang baik pada aktivitas kerja karyawan. Oleh karena itu, seorang karyawan harus menaruh minat yang tinggi pada suatu pekerjaan. Apabila seorang karyawan menaruh minat yang tinggi pada suatu pekerjaan tertentu, maka pekerjaan tersebut akan terselesaikan dengan baik.

Kepribadian merupakan jumlah total dari cara dimana seorang individu bereaksi dan berinteraksi dengan orang lain. Setiap orang pasti memiliki keperibadian yang berbeda. Oleh karena itu, orang tersebut harus bekerja sesuai dengan kepribadiannya. Kemampuan yang dimiliki individu untuk melakukan suatu pekerjaan; bakat, minat dan faktor kepribadian. Dengan demikian, seorang karyawan akan mempunyai kinerja yang baik jika karyawan tersebut memiliki tingkat keterampilan, maka karyawan tersebut akan menghasilkan kinerja yang baik juga.

\section{Usaha Individu}

Menurut Malthies (2006), yang mempengaruhi usaha ada empat, yaitu motivasi, etika kerja, ketidakhadiran dan rancangan tugas dan pekerjaan. Motivasi adalah kesediaan untuk mengeluarkan tingkat upaya yang tinggi untuk tujuan organisasi, yang dikondisikan oleh kemampuan upaya itu dalam memenuhi beberapa kebutuhan individual. Etika berhubungan dengan apa yang seharusnya 
dilakukan. Bagi para profesional sumber daya manusia, ini merupakan cara dimana manajer seharusnya bertindak sehubungan dengan persoalan sumber daya manusia yang ada.

Karyawan boleh tidak hadir kerja untuk beberapa alasan. Misalnya karena sakit, kematian dalam keluarga, dan alasan-alasan pribadi lainnya atas ketidakhadiran yang tidak dapat dihindari dan dapat dimengerti. Akan tetapi, banyak ketidakhadiran merupakan ketidakhadiran yang dapat dihindari atau dengan sengaja. Para karyawan akan cenderung bisa bekerja dengan baik apabila diberi tanggung jawab dan otomi kerja, keseimbangan kerja atau kehidupan dan kondisi kerja yang memungkinkan. Tingkat usaha yang dicurahkan oleh tiap individu. Usaha tersebut dapat berupa semangat kerja, etika kerja, dan tingkat kehadiran.

\section{Dukungan Perusahaan}

Menurut Payaman (2005), kinerja setiap karyawan dapat ditingkatkan melalui dukungan organisasi atau perusahaan antara lain: (1) struktur organisasi yang memuat pembagian tugas yang jelas, serta struktur kewenangan dan pelaporan pertanggung jawaban yang pasti; (2) penyediaan sarana dan peralatan kerja yang lengkap termasuk pilihan penggunanan teknologi yang tepat; (3) penyediaan tempat dan lingkungan kerja yang nyaman, aman, dan sehat, didukung oleh penyediaan kelembagaan, peralatan dan sarana perlindungan keselamatan dan keselamatan kerja; (4) penyediaan kondisi dan syarat kerja termasuk pengupahan dan jaminan sosial yang di satu pihak dapat mendorong pertumbuhan perusahaan dan dipihak lain dapat meningkatkan kesejahteraan, pekerja dan keluarganya; (5) memberi peluang bagi perusahaan dan pekerja membangun hubungan industrial yang aman dan harmonis, termasuk kesempatan bernegosiasi untuk merumuskan perjanjian kerjasama; dan (6) menyediakan kecukupan anggaran yang dibutuhkan untuk setiap pelaksanaan tugas.

Menurut Matthis (2006), dukungan organisasi merupakan apa saja yang diberikan dan ditetapkan perusahaan untuk menunjang proses kerja. Beberapa dukungan organisasi yang mempengaruhi kinerja karyawan, antara lain: (1) pelatihan, sebuah proses dimana orang mendapatkan kapabilitas untuk membantu pencapaian tujuan-tujaun organisasional. Dalam pengertian terbatas, pelatihan memberikan karyawan pengetahuan dan keterampilan yang spesifik dan dapat diidentifikasi untuk digunakan dalam pekerjaan mereka saat ini; (2) standar kinerja, mendefinisikan tingkat yang diharapkan dari kinerja, dan merupakan tujuan atau target. Standar kinerja yang realistis, dapat diukur, dipahami dengan jelas, akan bermanfaat baik bagi organisasi atau karyawannya; (3) peralatan dan teknologi, merupakan perlengkapan yang disediakan oleh perusahaan untuk menunjang proses kerja. Untuk mendapatkan kinirja yang baik dari karyawannya, maka sebuah perusahaan harus mempunyai peralatan dan teknologi yang mendukung.

Dukungan dari perusahaan dapat berupa suasana kerja yang mendukung, pelatihan, manajemen dan rekan kerja. Dukungan perusahaan dapat mempengaruhi kinerja karyawan dalan melakukan pekerjaan.

\section{Kinerja}

Secara sederhana kinerja dapat diartikan sebagai hasil yang dicapai oleh seorang karyawan selama periode waktu tertentu pada bidang pekerjaan tertentu. Seorang karyawan yang memiliki kinerja yang tinggi dan baik dapat menunjang tercapainya tujuan dan sasaran yang telah ditetapkan oleh perusahaan. Untuk dapat memiliki kinerja yang tinggi dan baik, seorang karyawan dalam melaksanakan tugasnya harus memiliki keahlian dan ketrampilan yang sesuai dengan pekerjaan yang dimilikinya.

Menurut Mangkunegara (2000), kinerja karyawan adalah hasil kerja baik secara kualitas maupun kuantitas dalam melaksanakan tugas yang diberikan. Menurut Mathies dan Jackson (2006), kinerja pada dasarnya adalah apa yang dilakukan atau tidak dilakukan oleh para karyawan. Kinerja 
karyawan adalah yang mempengaruhi seberapa banyak mereka memberi kontribusi kepada organisasi. Perbaikan kinerja baik untk individu maupun kelompok menjadi pusat perhatian dalam upaya meningkatkan kinerja organisasi.

Dalam jurnal Sumber Daya Manusia mengenai program pengembangan karir, kinerja karyawan banyak dipengaruhi oleh perhatian manajemen terhadap kebutuhan karyawan, salah satu diantaranya adalah dengan diperolehnya posisi pekerjaan yang sesuai dengan bakat, minat dan kemampuannya. Masih sedikit perusahaan yang merencanakan dan mengembangkan karir karyawan dengan dasar dan pertimbangan yang jelas dan terukur. Apabila kondisi tersebut tidak segera diperbaiki akan sangat berdampak pada hilangnya motivasi karyawan untuk menunjukkan kinerja terbaiknya. Pengembangan karir dan motivasi secara bersama-sama memberikan pengaruh positif signifikan terhadap variabel kinerja.

Karir seseorang dalam suatu organisasi banyak ditentukan oleh bagaimana kebijakan dan komitmen organisasi tersebut terhadap karyawannya dalam hal-hal sejauh mana rekrutmen dibatasi, sejauh mana kesempatan promosi ke jabatan yang lebih tinggi berasal dari dalam, sejauh mana terbuka kesempatan pelatihan dan pengembangan dan Sejauh mana komitmen perusahaan terhadap jaminan kelangsungan karyawan. Perusahaan yang berorientasi pada karir semacam ini akan memperlakukan karyawan sebagai sumber daya yang berharga, yang harus dilatih, kembangkan dan dipertahankan.

Menurut Dessler (2004), menilai kinerja adalah kegiatan membandingkan kinerja aktual bawahan dengan standar-standar yang telah ditetapkan. Pada dasarnya pemberian kinerja merupakan evaluasi tehadap perilaku prestasi kerja, dan potensi pengembangan yang telah dilakukan dan merupakan suatu proses dalam menentukan nilai keberhasilan pelaksanaan tugas karyawan serta menjadi pembanding antara realitas kerja dengan prestasi yang telah dicapai oleh karyawan.

Penilaian kinerja dapat didefinisikan sebagai prosedur apa saja yang meliputi: penetapan standar kinerja, Penilaian kinerja aktual karyawan dalam hubungan dengan standar-standar yang telah ditetapkan dan Memberikan umpan balik pada karyawan dengan tujuan memotivasi orang tersebut untuk menghilangkan penurunan kinerja.

Menurut Wibowo (2007), kinerja merupakan hasil pekerjaan yang mempunyai hubungan yang kuat dengan tujuan strategis organisasi, kepuasan konsumen, dan memberikan kontribusi pada ekonomi. Dari pengertian kinerja tersebut dapat disimpulkan bahwa kinerja merupakan suatu hasil kerja yang dilakukan oleh individu atau organisasi dalam menyelesaikan suatu pekerjaan.

Mengenai manfaat penilaian kinerja, Handoko (2000) mengemukakan: (1) perbaikan prestasi kerja atau kinerja, umpan balik pelaksanaan kerja mernungkinkan karyawan, manajer dan departemen personalia dapat memperbaiki kegiatan-kegiatan mereka untuk meningkatkan prestasi; (2) penyesuaian-penyesuaian kompensasi, evaluasi prestasi keja membantu para pengambil keputusan dalam menentukan kenaikan upah, pemberian bonus dan bentuk kompensasi iainnya; (3) keputusankeputusan penempatan, promosi dan transfer biasanya didasarkan atas prestasi kerja atau kinerja masa lalu atau antisipasinya; (4) perencanaan kebutuhan latihan dan pengembangan, prestasi kerja atau kinerja yang jelek mungkin menunjukkan perlunya latihan. Demikian pula sebaliknya, kinerja yang baik mungkin mencerminkan potensi yang harus dikembangkan; (5) perencanaan dan pengembangan karir, umpan balik prestasi mengarahkan keputusan-keputusan karir, yaitu tentang jalur karir tertentu yang harus diteliti; (6) mendeteksi penyimpangan proses staffing, prestasi kerja yang baik atau buruk adaiah mencerminkan kekuatan atau kelemahan prosedur staffing departemen personalia; (7) melihat ketidakakuratan informasional, prestasi kerja yanng jelek mungkin menunjukkan kesalahan-kesalahan dalam informasi analisis jabatan, rencana sumberdaya manusia, atau komponenkomponen lain system informasi manajemen personalia. Menggantungkan pada informasi yang tidakakurat dapat rnenyebabkan keputusan-kcpulusan personalia tidak tepat; (8) Mendeteksi kesalahan-kesalahan desain pekerjaan, prestasi kerja yang jelek mungkin merupakan tanda kesalahan dalam desain pekerjaan. 
Penilaian prestasi membantu diagnosa kesalahan-kesalahan tersebut; (9) menjamin kesempatan kerja yang adil, penilaian prestasi kerja yang akurat akan menjamin keputusan-keputusan penempatan internal diambil tanpa diskriminasi; (10) melihat tantangan-tantangan ekternal, kadang-kadang prestasi seseorang dipengaruhi oleh faktor-faktor diluar lingkungan kerja, seperti keluarga, kesehatan, dan masalah-masalah pribadi lainnya.

\section{Elemen kinerja dan Model Perencanaan Kinerja}

Menurut Robert dan John (2006), kinerja yang umumnya untuk kebanyakan pekerjaan meliputi elemen sebagai berikut: Kuantitas dari hasil, Kualitas dari hasil, Ketepatan waktu dari hasil dan Kemampuan bekerja sama. Menurut Payaman (2005), perencanaan kinerja merupakan proses penyusunan rencana kegiatan untuk meningkatkan kinerja perusahaan dan kinerja setiap orang. Rencana kerja terdiri dari tiga komponen, yaitu: uraian jabatan atau uraian tugas, sasaran kinerja dan rencana tindakan kinerja.

\section{Kerangka Pemikiran}

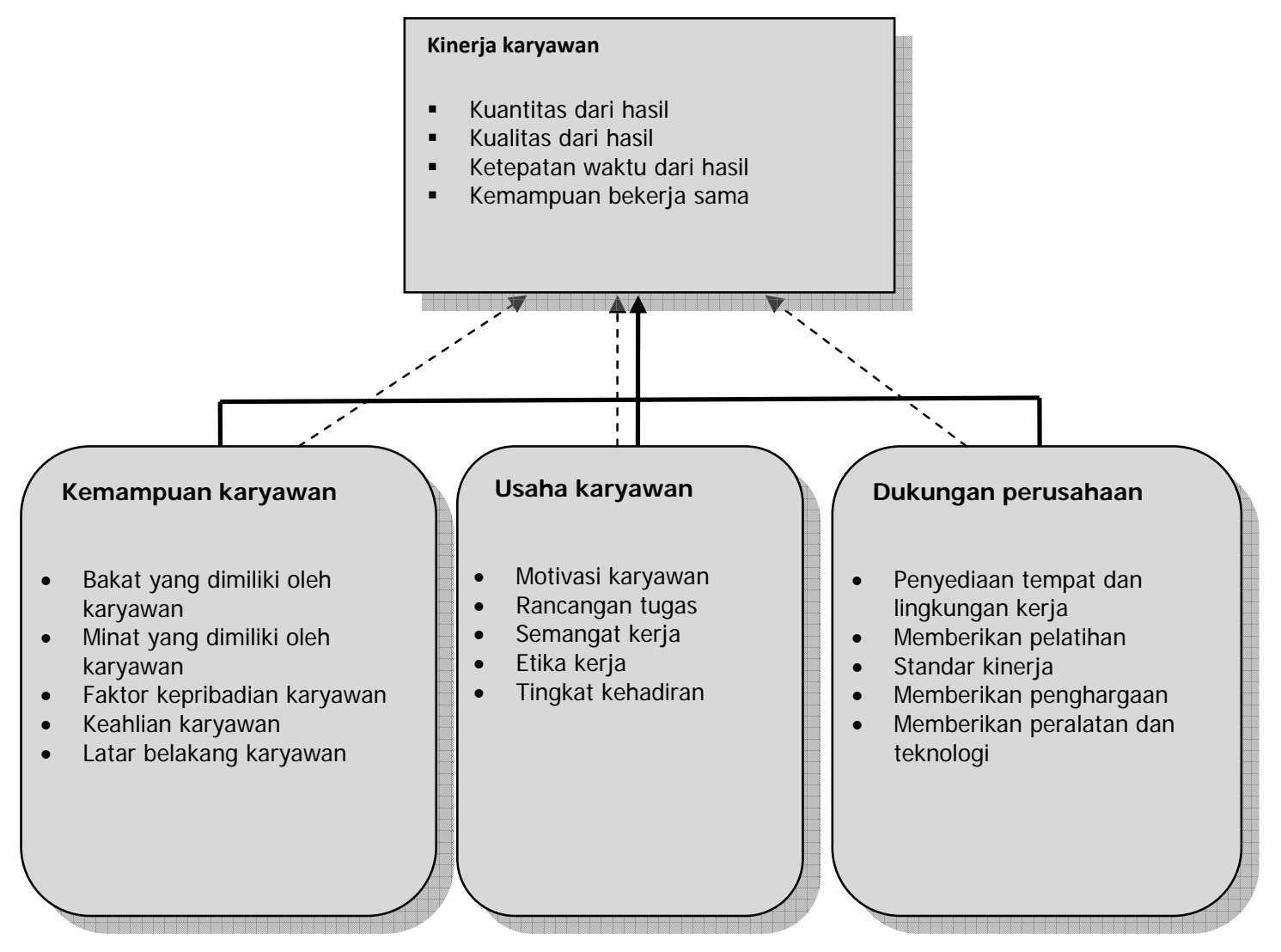

Gambar 1. Kerangka Pemikiran

Sumber : Diolah Penulis (2011) 


\section{METODE}

Tabel 1 Desain Penelitian

\begin{tabular}{|c|c|c|c|c|}
\hline \multirow[b]{2}{*}{$\begin{array}{l}\text { Tujuan } \\
\text { Penelitian }\end{array}$} & \multicolumn{4}{|c|}{ Desain Riset } \\
\hline & $\begin{array}{c}\text { Jenis } \\
\text { Penelitian }\end{array}$ & $\begin{array}{c}\text { Metode } \\
\text { Penelitian }\end{array}$ & Unit Analisis & Time Horizone \\
\hline $\mathrm{T}-1$ & Asosiatif & Survey & $\begin{array}{l}\text { Individu Karyawan CV Sandang Gloria } \\
\text { Konveksindo }\end{array}$ & Cross Selection \\
\hline $\mathrm{T}-2$ & Asosiatif & Survey & $\begin{array}{l}\text { Individu Karyawan CV Sandang Gloria } \\
\text { Konveksindo }\end{array}$ & Cross Selection \\
\hline $\mathrm{T}-3$ & Asosiatif & Survey & $\begin{array}{l}\text { Individu Karyawan CV Sandang Gloria } \\
\text { Konveksindo }\end{array}$ & Cross Selection \\
\hline $\mathrm{T}-4$ & Asosiatif & Survey & $\begin{array}{l}\text { Individu Karyawan CV Sandang Gloria } \\
\text { Konveksindo }\end{array}$ & Cross Selection \\
\hline
\end{tabular}

Di mana:

T-1 = Pengaruh kemampuan karyawan tehadap kinerja karyawan

$\mathrm{T}-2$ = Pengaruh usaha karyawan tehadap kinerja karyawan

T-3 = Pengaruh Dukungan Perusahaan tehadap kinerja karyawan

$\mathrm{T}-4$ = Pengaruh kemampuan karyawan, usaha karyawan, dukungan perusahaan terhadap kinerja karyawan

Tabel 2 Operasionalisasi Variabel Penelitian

\begin{tabular}{|c|c|c|c|c|}
\hline Variabel & Konsep variabel & Indicator utama & Ukuran & $\begin{array}{l}\text { Model Skala } \\
\text { pengukuran }\end{array}$ \\
\hline Kemampuan & $\begin{array}{l}\text { Kemampuan yang } \\
\text { dimiliki oleh individu } \\
\text { untuk melakukan suatu } \\
\text { pekerjaan; yaitu bakat, } \\
\text { minat, dan factor } \\
\text { kepribadian. }\end{array}$ & $\begin{array}{l}\text { - } \text { Bakat yang dimiliki oleh karyawan } \\
\text { - } \text { Minat yang dimiliki oleh karyawan } \\
\text { - Faktor kepribadian karyawan } \\
\text { - Keahlian karyawan } \\
\text { - Latar belakang karyawan }\end{array}$ & Interval & Likert \\
\hline Usaha & $\begin{array}{l}\text { Tingkat usaha yang } \\
\text { dicurahkan oleh tiap } \\
\text { individu.Usaha tersebut } \\
\text { dapat berupa semangat } \\
\text { kerja, etika kerja, dan } \\
\text { tingkat kehadiran. }\end{array}$ & $\begin{array}{l}\text { - Motivasi karyawan } \\
\text { - Rancangan tugas } \\
\text { - Semangat kerja } \\
\text { - Etika kerja } \\
\text { - Tingkat kehadiran }\end{array}$ & Interval & Likert \\
\hline Dukungan & $\begin{array}{l}\text { Dukungan dari } \\
\text { perusahaan. Dukungan } \\
\text { tersebut dapat berupa } \\
\text { suasana kerja yang } \\
\text { mendukung, pelatihan, } \\
\text { manajemen dan rekan } \\
\text { kerja. }\end{array}$ & $\begin{array}{l}\text { - Penyediaan tempat dan lingkungan } \\
\text { kerja } \\
\text { - Memberikan pelatihan } \\
\text { - Standar kinerja } \\
\text { - Memberikan penghargaan } \\
\text { - Memberikan peralatan dan } \\
\text { teknologi }\end{array}$ & Interval & Likert \\
\hline $\begin{array}{l}\text { Kinerja } \\
\text { karyawan }\end{array}$ & $\begin{array}{l}\text { Hasil dari kerja } \\
\text { karyawan, baik secara } \\
\text { kualitas maupun } \\
\text { kuantitas dalam } \\
\text { melaksanakan tugas } \\
\text { yang diberikan. }\end{array}$ & $\begin{array}{l}\text { - Kuantitas dari hasil } \\
\text { - Kualitas dari hasil } \\
\text { - Ketepatan waktu dari hasil } \\
\text { - Kemampuan bekerja sama }\end{array}$ & Interval & Likert \\
\hline
\end{tabular}




\section{Sumber Data Penelitian}

Berdasarkan Sugiyono (2004), pengumpulan data dapat di gunakan sumber data primer dan data sekunder. Sumber primer adalah sumber data yang langsung memberikan data kepada pengumpul data, dan sumber sekunder merupakan sumber yang tidak langsung memberikan data pada pengumpul data.

Tabel 3 Jenis Data Penelitian

\begin{tabular}{|c|c|}
\hline Jenis Data & Sumber Data \\
\hline Kemampuan karyawan & $\begin{array}{l}\text { Data primer dari CV SANDANG GLORIA KONVEKSINDO dengan } \\
\text { menggunakan kuisioner. }\end{array}$ \\
\hline Usaha karyawan & $\begin{array}{l}\text { Data primer dari CV SANDANG GLORIA KONVEKSINDO dengan } \\
\text { menggunakan kuisioner. }\end{array}$ \\
\hline Dukungan perusahaan & $\begin{array}{l}\text { Data primer dari CV SANDANG GLORIA KONVEKSINDO dengan } \\
\text { menggunakan kuisioner. }\end{array}$ \\
\hline $\begin{array}{l}\text { Sejarah dan struktur } \\
\text { perusahaan }\end{array}$ & Data sekunder dari CV SANDANG GLORIA KONVEKSINDO. \\
\hline
\end{tabular}

\section{Teknik Pengumpulan Data}

Dalam penelitian ini, teknik pengumpulan data yang di gunakan adalah wawancara dan kuisioner. Melalui kuisioner dengan cara membagikan kuisioner kepada responden yang merupakan karyawan dari CV Sandang Gloria Konveksindo.

Tabel 4 Tujuan penelitian dan metode analisis

\begin{tabular}{cc}
\hline Tujuan Penelitian & Metode Analisis \\
\hline T-1 & Regresi Sederhana \\
T-2 & Regresi Sederhana \\
T-3 & Regresi Sederhana \\
T-4 & Regresi Berganda \\
\hline Tujuan Penelitian & Metode Analisis \\
\hline T-1 & Regresi Sederhana \\
T-2 & Regresi Sederhana \\
T-3 -4 & Regresi Sederhana \\
\hline
\end{tabular}

Berdasarkan Sugiyono (2004), pengumpulan data dapat dilakukan dalam berbagai setting, berbagai sumber, dan berbagai cara. Bila di lihat dari settingnya, data dapat di kumpulkan pada setting alamiah pada laboratorium dengan metode eksperimren, di rumah dengan berbagai responden, pada suatu seminar, diskusi, dijalan dan lain-lain. Pengumpulan data berdasarkan tekniknya, yaitu: wawancara dan kuesioner.

Untuk Kuisioner yang merupakan data yang dikumpulkan dengan member pertanyaan kepada karyawan melalui daftar pertanyaan yang terstruktur. Dengan kuisioner, dapat diperoleh data seperti sikap, perasaan atau pengetahuan responden. Kuisioner dalam penelitian ini dibuat dengan skala likert dengan pemberian bobot seperti berikut: Sangat Setuju $(\mathrm{SS})=5$, Setuju $(\mathrm{S})=4$, Ragu-ragu $(\mathrm{R})=3$, Kurang Setuju $(\mathrm{KS})=2$ dan Tidak Setuju $(\mathrm{TS})=1$. 
Skala ini mudah dipakai, baik untuk penelitian yang berfokus pada responden dan yang berfokus pada objek. Jadi, kita dapat mempelajari respons berbeda dari satu orang ke orang lain dan bagaimana respons berbeda antara berbagai objek.

$$
\text { rata }- \text { rata nilai }=\frac{\sum(\mathrm{XiYi})}{N}
$$

Di mana:

$$
\begin{array}{ll}
\sum_{\mathrm{Xi}}(\mathrm{XiYi}) & \text { : Nilai total responden } \\
\mathrm{Xi} & \text { : Nilai pernyataan } \\
\mathrm{Yi} & \text { : Jumlah responden } \\
\mathrm{N} & \text { : Jumlah total responden }
\end{array}
$$

Menurut Sugiyono (2003) dalam skala likert, kemungkinan jawaban bukan hanya setuju atau tidak setuju, tetapi dibuat dengan lebih banyak jawaban. Instrumen penelitian dalam kuisioner atau wawancara secara langsung ini, menggunakan Skala Likert yang berbentuk pilihan ganda (checklist). Penulis mengumpulkan sejumlah pertanyaan yang berkaitan dengan masalah yang akan diteliti, kemudian responden memilih salah satu jawaban dari sejumlah kategori jawaban yang tersedia, atau menjawab langsung pertanyaan tanpa harus memilih kategori jawaban yang tersedia.

\section{Metode Analisis}

Di dalam suatu penelitian, data merupakan hal yang terpenting karena menggambarkan variabel-variabel yang diteliti dan berfungsi sebagai alat pembuktian hipotesis.

\section{HASIL DAN PEMBAHASAN}

\section{Profil CV Sandang Gloria Konveksindo}

Di era globalisasi persaing bisnis semakin ketat, kebutuhan suatu perusahaan sangat tergantung pada kualitas Sumber Daya Manusia (SDM) yang menjalankan bisnis tersebut. CV Sandang Gloria Konveksindo merupakan perusahaan dagang yang bergerak dalam bidang penjualan kebutuhan barang sandang. Perusahaan ini khususnya memproduksi pakaian dalam pria dan kaos oblong. Sandang Gloria Konveksindo berdiri pada tahun 1999 dan resmi menjadi CV Sandang Gloria Konveksindo pada tanggal 26 May 2007. Perusahaan ini berlokasi di jalan. FF no.32 Sukabumi Selatan, Kebon Jeruk, Jakarta Barat.

Pada periode perjalanannya CV sandang Gloria Konveksindo bermula dari suatu keadaan dimana banyak berkembangnya bisnis dibidang produksi barang sandang, mulai dari proses pembuatan bahan baku sampai menjadi barang jadi serta menjual dan mendistribusikan barang produksi tersebut kepada agen-agen yang tersebar dibeberapa daerah di Indonesia, seperti di Bali, Medan, Jawa dan sekitarnya. Bisnis ini berkembang karena semakin meningkatnya kebutuhan barang sandang di Indonesia. Dengan banyak berkembangnya bisnis dibidangini, maka CV sandang Gloria Konveksindo melihat bahwa ada banyak peluang untuk mendirikan perusahaan dalam menjual produk barang sandang. Mengingat semakin tingginya persaiang dalam bidang ini, mengharuskan $\mathrm{CV}$ sandang Gloria Konveksindo meningkatkan pelayanan, dan kualitas dari barang-barang yang akan dijualnya. 


\section{Profil Responden}

Berdasarkan hasil penelitian yang telah dilakukan terhadap 46 responden (karyawan CV Sandang Gloria Konveksindo maka dapat diketahui profil responden berdasarkan jenis kelamin, usia, jenjang pendidikan, dan lamanya masa kerja di perusahaan.

\section{Komposisi Karyawan Berdasarkan Jenis Kelamin}

Profil responden berdasarkan jenis kelamin, dari 46 pekerja; 14 orang (30\%) pekerja pria dan 32 orang $(70 \%)$ pekerja wanita.

\section{Komposisi Karyawan berdasarkan Jenjang Usia}

Profil responden berdasarkan jenjang usia, dari 46 pekerja; 24 orang (52\%) pekerja yang berusia kurang dari 25 tahun, 8 orang (17\%) pekerja yang berusia 25 sampai 30 tahun, 9 orang (20\%) berusian 31 sampai 35 tahun, dan 5 orang (11\%) yang berusia diatas 35 tahun.

\section{Komposisi Karyawan berdasarkan jenjang pendidikan}

Profil responden berdasarkan jenjang pendidikan, dari 46 pekerja; 28 orang (61\%) pekerja lulusan SMP dan 18 orang (39\%) pekerja lulusan SMA.

\section{Komposisi Karyawan berdasarkan Masa Kerja}

Profil responden berdasarkan masa kerja, dari 46 pekerja; 6 orang (13\%) pekerja bekerja selama kurang dari satu tahun, 15 orang (33\%) pekerja bekerja selama satu sampai lima tahun dan 25 orang $(54 \%)$ pekerja bekerja selama tiga sampai lima tahun.

\section{Analisis Pengaruh Kemampuan Karyawan terhadap Kinerja Karyawan CV Sandang Gloria Konveksindo}

Analisis regresi dilakukan untuk mengetahui pengaruh kemampuan karyawan terhadap kinerja karyawan CV Sandang Gloria Konveksindo. Dari hasil penghitungan SPSS terdapat kolom (R) yaitu kolerasi dan (R Square) yaitu determinasi. Pada tabel diatas kolom (R) tertulis angka 0.537 yang artinya besarnya kolerasi $=0.537$. Artinya $: 0.537>0.05$ berarti mempunyai hubungan yang kuat dan searah, dan juga mempunyai arti jika variabel kemampuan karyawan nilainya naik, maka variabel $\mathrm{Y}$ nilainya juga akan naik.

Selain itu dari hasil model summary terdapat kolom (R square) dengan angka 0.288 artinya untuk mencari persentasenya harus dikalikan dengan $100 \%$, jadi $0.288 \times 100 \%=28,8 \%$ variabel $\mathrm{Y}$ dipengaruhi oleh variabel kemampuan karyawan sisanya sebanyak $71,2 \%$ dipengaruhi variabel lain.

Hal di atas menggambarkan persamaan regresi sebagai berikut:

$$
\mathrm{Y}=0.784+0.537 \mathrm{X}_{1}
$$

Keterangan :

$\mathrm{Y}=$ Kinerja Karyawan

$\mathrm{X}_{1}=$ Kemampuan karyawan 
Dari hasil persamaan regresi terlihat bahwa: (1) jika tidak ada variabel independen (kemampuan karyawan) atau $\left(\mathrm{X}_{1}=0\right)$ maka peningkatan kinerja karyawan yaitu sebesar 0.784 ; (2) koefisien regresi sebesar 0.537 menyatakan bahwa setiap pengurangan dan penambahan (karena tanda - dan + ) satu skor atau nilai kemampuan akan memberikan kenaikan skor sebesar 0.537 .

\section{Analisis Pengaruh Usaha Karyawan Terhadap Kinerja Karyawan CV Sandang Gloria Konveksindo}

Analisis regresi dilakukan untuk mengetahui pengaruh usaha karyawan terhadap kinerja karyawan CV Sandang Gloria Konveksindo. Dari hasil model summary terdapat kolom (R) yaitu kolerasi dan (R Square) yaitu determinasi. Pada tabel diatas kolom (R) tertulis angka 0.712 yang artinya besarnya kolerasi $=0.712$. Artinya $: 0.537>0.05$ berarti mempunyai hubungan yang kuat dan searah, dan juga mempunyai arti jika variabel usaha karyawan nilainya naik, maka variabel Y nilainya juga akan naik.

Selain itu dari hasil model summary terdapat kolom (R square) dengan angka 0.506 artinya untuk mencari persentasenya harus dikalikan dengan $100 \%$, jadi $0.506 \times 100 \%=50,6 \%$ variabel $\mathrm{Y}$ dipengaruhi oleh variabel usaha karyawan sisanya sebanyak 49,4\% dipengaruhi variabel lain.

Berdasarkan hal diatas menggambarkan persamaan regresi sebagai berikut:

Keterangan :

$$
\mathrm{Y}=1.266+0.712 \mathrm{X}_{2}
$$

$\mathrm{Y}=$ Kinerja Karyawan

$\mathrm{X}_{2}=$ Usaha karyawan

Dari hasil persamaan regresi diatas terlihat bahwa: (1) jika tidak ada variabel independen (usaha karyawan) atau $\left(\mathrm{X}_{2}=0\right.$ ) maka peningkatan kinerja karyawan yaitu sebesar 1.266; (2) koefisien regresi sebesar 0.712 menyatakan bahwa setiap pengurangan dan penambahan (karena tanda - dan + ) satu skor atau nilai usaha akan memberikan kenaikan skor sebesar 0.712 .

\section{Analisis Pengaruh Dukungan Perusahaan Terhadap Kinerja Karyawan CV Sandang Gloria Konveksindo}

Analisis regresi dilakukan untuk mengetahui pengaruh dukungan perusahaan terhadap kinerja karyawan CV Sandang Gloria Konveksindo. Dari hasil model summary terdapat kolom (R) yaitu kolerasi dan (R Square) yaitu determinasi. Pada tabel diatas kolom (R) tertulis angka 0.688 yang artinya besarnya kolerasi $=0.688$. Artinya $: 0.688>0.05$ berarti mempunyai hubungan yang kuat dan searah, dan juga mempunyai arti jika variabel dukungan perusahaan nilainya naik, maka variabel $\mathrm{Y}$ nilainya juga akan naik.

Selain itu dari hasill model summary terdapat kolom (R square) dengan angka 0.506 artinya untuk mencari persentasenya harus dikalikan dengan $100 \%$, jadi $0.474 \times 100 \%=47,4 \%$ variabel $\mathrm{Y}$ dipengaruhi oleh variabel dukungan perusahaan sisanya sebanyak 52,6\% dipengaruhi variabel lain.

Berdasarkan hal diatas menggambarkan persamaan regresi sebagai berikut:

Keterangan :

$$
\mathrm{Y}=0.893+0.688 \mathrm{X}_{3}
$$

$\mathrm{Y}=$ Kinerja Karyawan

$\mathrm{X}_{3}=$ Dukungan perusahaan 
Dari hasil persamaan regresi diatas terlihat bahwa: (1) jika tidak ada variabel independen (dukungan perusahaan) atau $\left(\mathrm{X}_{3}=0\right)$ maka peningkatan kinerja karyawan yaitu sebesar 0.893 ; (2) koefisien regresi sebesar 0.688 menyatakan bahwa setiap pengurangan dan penambahan (karena tanda - dan + ) satu skor atau nilai dukungan perusahaan akan memberikan kenaikan skor sebesar 0.688 .

\section{Analisis Pengaruh Kemampuan Karyawan, Usaha Karyawan dan Dukungan Perusahaan terhadap Kinerja Karyawan CV Sandang Gloria Konveksindo}

Analisis regresi dilakukan untuk mengetahui pengaruh secara keseluruhan kemampuan karyawan, usaha karyawan dan dukungan perusahaan terhadap kinerja karyawan CV Sandang Gloria Konveksindo. Dari hasil model summary terdapat kolom (R) yaitu kolerasi dan (R Square) yaitu determinasi. Pada tabel diatas kolom $(\mathrm{R})$ tertulis angka 0.815 yang artinya besarnya kolerasi $=0.815$. Artinya : $0.815>0.05$ berarti mempunyai hubungan yang kuat dan searah, dan juga mempunyai arti jika variabel kemampuan karyawan, usaha karyawan dan dukungan perusahaan nilainya naik, maka variabel Y nilainya juga akan naik.

Selain itu dari hasil model summary terdapat kolom (R square) dengan angka 0.663 artinya untuk mencari persentasenya harus dikalikan dengan $100 \%$, jadi $0.663 \times 100 \%=66,3 \%$ variabel $\mathrm{Y}$ dipengaruhi oleh variabel kemampuan karyawan, usaha karyawan dan dukungan perusahaan sisanya sebanyak $33,7 \%$ dipengaruhi variabel lain.

Berdasarkan hal diatas menggambarkan persamaan regresi ganda sebagai berikut:

$$
Y=0.773+0.273 X_{1}+0.374 X_{2}+0.390 X_{3}
$$

Keterangan :

$\mathrm{Y}=$ Kinerja Karyawan

$\mathrm{X}_{1}=$ Kemampuan Karyawan

$\mathrm{X}_{2}=$ Usaha Karyawan

$\mathrm{X}_{3}=$ Dukungan perusahaan

Dari hasil persamaan regresi diatas terlihat bahwa: (1) jika tidak ada variabel independen (kemampuan kayawan, usaha karyawan dan dukungan perusahaan) atau $\left(\mathrm{X}_{1}, \mathrm{X}_{2}\right.$, dan $\left.\mathrm{X}_{3}=0\right)$ maka peningkatan kinerja karyawan yaitu sebesar -0.773 ; (2) koefisien regresi sebesar 0.273 ; 0.374 dan 0.390 menyatakan bahwa setiap pengurangan dan penambahan (karena tanda - dan + ) satu skor atau nilai kemampuan karyawan, usaha karyawan dan dukungan perusahaan akan memberikan kenaikan skor sebesar $0.273 ; 0.374$ dan 0.390 . 


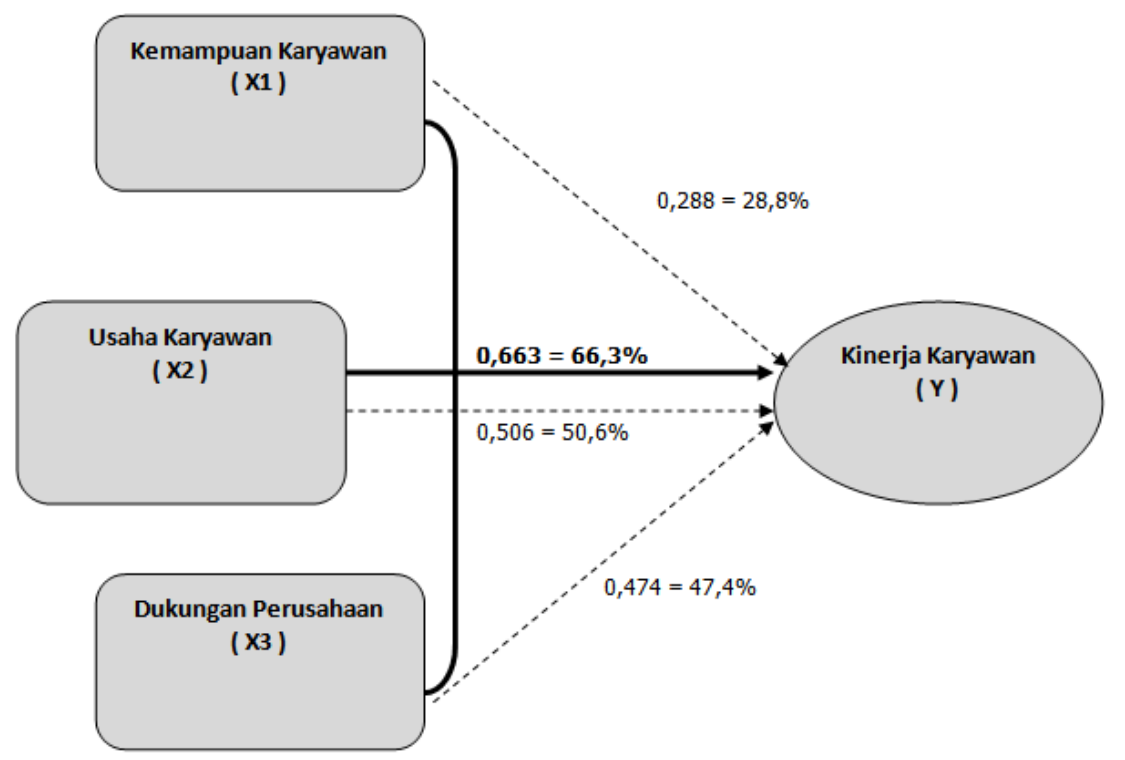

Gambar 2 Hasil Analisis Pengaruh Kemampuan Karyawan, Usaha Karyawan dan Dukungan Perusahaan Terhadap Kinerja karyawan Sumber: Hasil Pengolahan Data (2011)

\section{Implikasi Hasil Penelitian}

Setelah dilakukan analisis pengaruh antara kemampuan karyawan terhadap kinerja karyawan sebesar 0,288 atau 28,8\%, maka diperoleh kesimpulan bahwa kemampuan karyawan CV Sandang Gloria Konveksindo terdapat pengaruh yang cukup kuat terhadap kinerja karyawan. Hal ini dimungkinkan pula karena 52\% karyawan berusia muda (dibawah 25 tahun) Ini menunjukan bahwa saat ini CV Sandang Gloria Konveksindo menuntut karyawannya untuk lebih meningkatkan kemampuannya dalam bekerja apalagi usia mereka yang relatif masih muda jadi masih bisa lebih ditingkatkan lagi. Setelah dilakukan analisis pengaruh antara usaha karyawan terhadap kinerja karyawan sebesar 0,506 atau 50,6\%, maka diperoleh kesimpulan bahwa usaha karyawan CV Sandang Gloria Konveksindo terdapat pengaruh yang kuat terhadap kinerja karyawan. Ini menunjukan bahwa saat ini CV Sandang Gloria Konveksindo menuntut karyawannya untuk memiliki usaha dalam bekerja. Hal ini juga dipengaruhi oleh profil karyawan yang 100\% tingkat pendidikan SMP dan SMA.

Setelah dilakukan analisis pengaruh antara dukungan perusahaan terhadap kinerja karyawan sebesar 0,474 atau 47,4\%, maka diperoleh kesimpulan bahwa dukungan perusahaan CV Sandang Gloria Konveksindo terdapat pengaruh yang kuat terhadap kinerja karyawan. Ini menunjukan bahwa saat ini CV Sandang Gloria Konveksindo menuntut perusahaannya untuk lebih mendukung karyawannya. Bila dilihat lebih jauh, pengaruh secara keseluruhan kemampuan karyawan, usaha karyawan dan dukungan perusahaan memiliki pengaruh yang signifikan terhadap kinerja karyawan yaitu sebesar 0.663 atau 66,3\%. Ini menunjukan bahwa kinerja karyawan CV sandang Gloria Konveksindo dipengaruhi oleh kemampuan, usaha dan dukungan perusahaan. Ini menunjukan bahwa kemampuan karyawan, usaha karyawan, dan dukungan perusahaan akan memberikan pengaruh yang sangat besar terhadap kinerja karyawan CV sandang Gloria Konveksindo. Maka dari itu, karyawan CV sandang Gloria Konveksindo seharusnya meningkatkan kemampuan, usaha, dan dukungan perusahaan agar dapat meningkatkan kinerja karyawan dan berdampak pada meningkatnya kinerja perusahaan. 


\section{SIMPULAN}

Kemampuan karyawan memiliki pengaruh sebesar 28,8\% terhadap kinerja karyawan CV Sandang Gloria Konveksindo. Hal tersebut dapat diambil kesimpulan bahwa para karyawan harus lebih meningkatkan kemampuannya, seperti meningkatkan bakat, minat, serta keahlian yang dimiliki. Karena kemampuan cukup berpengaruh terhadap kinerja karyawan. Usaha karyawan memiliki pengaruh sebesar 50,6\% terhadap kinerja karyawan CV Sandang Gloria Konveksindo. Hal tersebut dapat diambil kesimpulan bahwa usaha karyawan dalam bekerja sangat berpengaruh terhadap kinerja karyawan. Para karyawan harus lebih meningkatkan motivasinya, semangat dalam bekerja, dan berusaha menghindari absen di tempat kerja. Dukungan perusahaan memiliki pengaruh sebesar 47,4\% terhadap kinerja karyawan CV Sandang Gloria Konveksindo. Hal tersebut dapat diambil kesimpulan bahwa saat ini dukungan perusahaan berpengaruh terhadap kinerja karyawan. Dukungan tersebut dapat berupa penyediaan tempat dan lingkungan kerja yang nyaman, peralatan dan teknologi yang menunjang proses kerja, serta pelatihan dan pengembangan yang dibutuhkan oleh para karyawan. Semakin baik dukungan yang diberikan oleh perusahaan, maka kinerja karyawan akan semakin meningkat. Kemampuan karyawan, usaha karyawan, dan dukungan perusahaan memiliki pengaruh yaitu sebesar 66,3\% terhadap kinerja karyawan CV Sandang Gloria Konveksindo. Oleh karena itu, karyawan CV Sandang Gloria Konveksindo seharusnya lebih meningkatkan kemampuan karyawan, usaha karyawan, dan dukungan perusahaan agar dapat meningkatkan kinerja karyawan dan berdampak pada meningkatnya kinerja perusahaan.

\section{DAFTAR PUSTAKA}

Dessler, G. (2004). Manajemen sumber daya manusia. Jakarta: Index Kelompok Gramedia.

Handoko, T. H. (2000). Manajemen personalia dan sumber daya manusia. Yogyakarya: BPFE.

Mangkunegara, A. A., \& Prabu, A. (2000). Manajemen sumber daya manusia perusahaan. Bandung: Remaja Posdakarya.

Sugiyono. (2003). Statistika untuk penelitian. Bandung: Alfabeta.

Sugiyono. (2008). Mandiri belajar SPSS. Yogyakarta: MediaKom.

Wibowo. (2007). Manajemen kinerja. Jakarta: Rajagrafindo Persada. 